\title{
Uma estudante de nutrição no Conselho Nacional de Segurança Alimentar e Nutricional
}

A nutrition student in national food and nutritional security

Prezados editores da revista DEMETRA: Alimentação, Nutrição छ̊ Saúde:

Dirijo-me aos senhores solicitando a publicação de meu relato de experiência, construído durante estágio complementar do curso de Nutrição da Universidade de Brasília. Escolhi esse periódico por sugestão da orientadora do estágio, Elisabetta Recine, professora do Departamento de Nutrição da Universidade de Brasília.

Através deste relato, espero poder falar sobre o que me possibilitou enxergar a Nutrição sob uma ótica diferente e, portanto, definir a saúde pública como minha área de atuação enquanto profissional. Assim, poderei contribuir para que estudantes conheçam e vivenciem uma nova abordagem da Nutrição.

Eis o meu depoimento:

"Se eu pudesse resumir 2012 em apenas uma palavra, essa palavra seria reconstrução. Por uma série de motivos, o ano que passou fez com que eu enxergasse minha vida profissional sob uma ótica diferente - talvez a ótica que eu viesse buscando desde o dia em que ingressei na universidade.

Quando marquei "Nutrição" no vestibular, eu não sabia ao certo o que me esperava. Eu me lembro de que estava em dúvida entre dois ou três cursos - a maioria da área de humanidades. Na verdade, ainda não me sentia preparada para tomar uma decisão tão importante quanto essa, e não conhecia ninguém que tivesse a Nutrição como seu curso de graduação ou profissão. Mas eu tinha uma única certeza: eu queria ajudar as pessoas; eu precisava ajudar de alguma forma. $\mathrm{E}$ a Nutrição, como curso da área da saúde, me pareceu o caminho mais viável. 
No segundo semestre de 2012, o Conselho Nacional de Segurança Alimentar e Nutricional (CONSEA) "apareceu" na minha vida. Na última etapa do curso de Nutrição da Universidade de Brasília (UnB), é necessário escolher uma área, geralmente a de maior afinidade - no meu caso, a área de Nutrição Social - para a realização do último estágio curricular, o estágio complementar. Entre as alternativas dos locais de estágio, estava o CONSEA. Difícil explicar os motivos que me levaram a escolher esse local... Na verdade, antes da reunião para decisão dos locais onde cada aluno/a realizaria seu estágio, eu já havia decidido para onde ir. O CONSEA apareceu, naquele momento, como uma nova alternativa, diferente do que havia sido ofertado nos semestres anteriores. Por alguma razão, tomei uma nova decisão, ali, na hora, sem hesitar. Eu queria ir pro CONSEA. Eu não sabia se esse seria o melhor estágio para mim. Não sabia se estava preparada para essa função. Mas eu coloquei na minha cabeça que tinha que ser o CONSEA. E assim foi.

No dia 13 de setembro de 2012, pisei no CONSEA pela primeira vez. E a partir de então começou o meu estágio - e minha transformação.

No início, a única vontade que senti foi de sair daquele lugar o mais rápido possível. Primeiramente, porque a minha função inicial era basicamente ler. Políticas, planos, relatórios. E, em segundo lugar, porque participei do meu primeiro evento dentro do CONSEA: A Mesa de Controvérsias sobre Agrotóxicos - e, de repente, tudo que eu vinha aprendendo em anos de faculdade, começou a ser posto em discussão.

A sensação que eu tinha nos meses iniciais de estágio era de que mais da metade do que eu já havia internalizado durante os anos de faculdade, na verdade não fazia muito sentido - existia, ainda, uma série de fatores por trás de cada questão que era abordada (e eu acho que as professoras estavam se esquecendo de me contar essa parte da história).

Não conseguia entender, por exemplo, o porquê de passar todo esse tempo na universidade aprendendo a incentivar meus clientes/pacientes a ingerir cinco porções de frutas e hortaliças por dia, enquanto o Brasil era o maior consumidor de agrotóxicos do mundo. Incentivando esse consumo eu iria promover saúde ou colocar esses indivíduos em risco? E esse era apenas um dos pontos que eu estava sendo instigada a questionar.

Quem eu sou? Quem eu quero ser, afinal? Estou feliz profissionalmente? O que sei sobre a minha profissão? O que eu realmente quero fazer com a Nutrição? Eu busco fazer o que realmente quero? O que a Nutrição pode realmente me ensinar? Estou onde eu queria estar? Afinal, por que a Nutrição? Por que eu estou questionando tudo isso agora? Por que, de repente, tudo que eu sabia sobre a Nutrição está me deixando tão confusa? 
Depois de meses de reflexão, enfim entendi. Atuando no CONSEA, eu estava exatamente onde eu queria estar. Estar exatamente onde eu queria estar foi exatamente o que me deixou assustada. Atuando no CONSEA, finalmente consegui o que eu realmente queria. E finalmente conseguir o que eu realmente queria provocou meu próprio desespero. Talvez porque eu sempre - ou há algum tempo - estivesse acostumada a estar onde eu não queria estar... E por isso andava me sentindo tão incompleta profissionalmente.

Esse foi o meu processo de reconstrução! Parece exagero, mas pela primeira vez, eu me senti enxergando a vida. Como ela realmente é. Como ela realmente deve ser enxergada. Como eu realmente sentia vontade de enxergá-la. Enfim, tudo estava começando a ficar claro... E eu não estou falando só da Nutrição. Estou falando da Nutrição Social. Da sociedade. Da saúde. Da vida, de uma maneira geral.

Eu não ouso dizer que estou transformada. Eu ouso dizer que mudei, mas que ainda me sinto em transformação... E o CONSEA tem uma grande parcela de "culpa" nesse processo. Por ter me dado a oportunidade de me manter em constante transformação, trabalhando com o público e com as ferramentas que eu sempre quis trabalhar, no fim das contas.

Quando eu me olho no espelho hoje, me pergunto por que demorou tanto tempo para eu entender tudo isso. Comparo datas e percebo que enquanto uma grande conferência acontecia em prol de questões ligadas à fome e à miséria, eu estava em casa, mexendo no computador ou em alguma saída, discutindo assuntos vazios - e, na maior parte das vezes, me sentindo vazia. Hoje sei o que está acontecendo no mundo e no meu país. Hoje sei onde buscar textos para me atualizar sobre as questões que realmente me interessam e que realmente importam. Hoje sei quais são os programas e as políticas que, de fato, são interessantes e eficazes. Hoje convivo diariamente com pessoas que sabem discutir sobre assuntos polêmicos e políticos. Hoje sei dizer o que é um gestor público, o que é um movimento social, o que é uma plenária. Hoje aprendi a direcionar meus questionamentos. E, por tudo isso, hoje me sinto muito mais perto de ser quem eu realmente quero ser.

O CONSEA foi meu grande passo. Foi o meu grande começo. Foi quem me abraçou apertado e me disse, bem baixinho: "Você é capaz. Você realmente pode fazer o que você quer fazer. Você realmente pode ser quem você quer ser. Acredite em si mesma e siga em frente. A sua vida profissional está só começando”.

Por tudo isso, eu só tenho a agradecer por essa oportunidade. O CONSEA foi mais do que um estágio curricular. Foi uma experiência de vida. Foi a minha transformação. Foi o meu processo de descoberta. E, mais do que tudo isso, foi a minha história de realização profissional. 
Assim, espero que, de alguma forma, eu possa contribuir para a formação de novos profissionais de Nutrição, que busquem perspectivas e formas de atuação diferentes daquelas convencionais e tão estimuladas na maioria das universidades, para que, enfim, seja possível a construção de multiplicadores de Segurança Alimentar e Nutricional."

Atenciosamente,

Bruna dos Santos Nunes

Recebido: 29/5/2013

Revisado: 18/6/2013

Aprovado: 06/8/2012 